\title{
Gambaran Perubahan Luka Memar pada Suku Minahasa
}

\author{
Nathasya A. F. Tilaar, ${ }^{1}$ Johannis F. Mallo, ${ }^{2}$ Djemi Tomuka ${ }^{2}$
}

\author{
${ }^{1}$ Progam Studi Pendidikan Dokter Fakultas Kedokteran Universitas Sam Ratulangi Manado \\ ${ }^{2}$ Bagian Ilmu Kedokteran Forensik dan Medikolegal Fakultas Kedokteran Universitas Sam \\ Ratulangi/RSUP Prof. Dr. R. D. Kandou \\ Email: aferildant@gmail.com
}

\begin{abstract}
Bruise is bleeding in the subcutaneous tissue due to rupture of capillaries and veins caused by blunt force. A forensic pathologist is usually asked about the time of bruise occurrence and this information is very important concerning to a medicolegal case. The ability to assess, document, and interpret injuries correctly is an important part of a doctor's task. This study was aimed to identify the color changes of bruise among Minahasan people. This was a prospective and descriptive study using sample observations. The results obtained 5 cases with bruises. In 1-4 days, the color of bruises was bluish red then turned to greenish yellow until days 10-12, and then it disappeared. In conclusion, there was no specific difference in bruise color of Minahasan people compared to previous studies.
\end{abstract}

Keywords: traumatology, bruise, Minahasan people

\begin{abstract}
Abstrak: Memar merupakan perdarahan dalam jaringan bawah kulit akibat pecahnya kapiler dan vena yang disebabkan oleh kekerasan benda tumpul. Seorang ahli forensik sering ditanyakan mengenai umur dari memar, dan informasi demikian dapat menjadi sangat penting dalam suatu kasus. Kemampuan menilai, mendoku-mentasikan, dan menginterpretasikan luka dengan tepat merupakan bagian penting dari tugas dokter. Penelitian ini bertujuan untuk mengidentifikasi perubahan warna luka memar pada orang yang berasal dari suku Minahasa. Jenis penelitian ialah deskriptif prospektif dalam observasi sampel. Hasil penelitian mendapatkan sebanyak 5 kasus dengan memar. Pada 1-4 hari memar berwarna merah kebiruan, berubah menjadi kuning kehijauan sampai pada hari ke 10-12 kemudian menghilang. Simpulan penelitian ini ialah tidak terdapat perbedaan spesifik pada memar orang suku Minahasa dibandingkan penelitian-penelitian sebelumnya.
\end{abstract}

Kata kunci: traumatologi, memar, suku Minahasa

\section{PENDAHULUAN}

Luka merupakan salah satu kasus tersering dalam Kedokteran Forensik. Luka disebabkan oleh karena adanya kekerasan. Kekerasan bisa berupa tindakan kekerasan fisik atau kekerasan psikologi. ${ }^{1}$ Secara medis, kekerasan adalah hilangnya kontinuitas jaringan yang disebabkan karena kekuatan dari luar dan dapat digolongkan menjadi kekerasan mekanik, kekerasan fisik, dan trauma kimiawi. Kekerasan mekanik terdiri dari kekerasan tumpul, kekerasan tajam, dan kekerasan akibat senjata api. ${ }^{2,3}$

Kekerasan tumpul merupakan kasus yang lebih umum ditemui. Luka akibat kekerasan tumpul adalah kerusakan jaringan yang disebabkan oleh benda atau alat yang tidak bermata tajam, konsistensi keras atau kenyal, dan permukaan halus atau kasar. $^{2}$ Kekerasan tumpul dapat menyebabkan tiga jenis luka yaitu luka memar (kontusio), luka lecet (abrasio), dan luka robek (vulnus laceratum). Dari ketiganya, luka memar yang paling sering ditemukan. ${ }^{4}$

Luka memar adalah luka tertutup di mana kerusakan jaringan di bawah kulit hanya tampak sebagai benjolan jika dilihat dari luar. Memar ini menimbulkan daerah 
kebiru-biruan atau kehitaman pada kulit. Bila terjadi pendarahan yang cukup, timbulnya pendarahan di daerah yang terbatas disebut hematoma. ${ }^{5}$ Letak, bentuk, dan luas luka memar dipengaruhi oleh berbagai faktor seperti besarnya kekerasan, jenis benda penyebab (karet, kayu, besi), kondisi dan jenis jaringan (jaringan ikat longgar, jaringan lemak), usia, jenis kelamin, corak dan warna kulit, kerapuhan pembuluh darah, dan penyakit (hipertensi, penyakit kardio vaskular, diathesis hemoragik). ${ }^{2,6}$ Pada bayi, hematom cenderung lebih mudah terjadi karena sifat kulit yang longgar dan masih tipisnya jaringan lemak subkutan, demikian pula pada usia lanjut sehubungan dengan menipisnya jaringan lemak subkutan dan pembuluh darah yang kurang terlindung. ${ }^{2,7}$

Dalamnya memar dan pigmentasi kulit dapat memberikan efek pada penampakan dan deteksi warna. ${ }^{8}$ Pada saat terjadi, memar berwarna merah, kemudian berubah menjadi ungu atau hitam; setelah 4-5 hari akan berwarna hijau yang kemudian akan berubah menjadi kuning dalam 7-10 hari, dan akhirnya menghilang dalam 14-15 hari. Perubahan warna tersebut berlangsung mulai dari tepi dan waktunya dapat bervariasi tergantung derajat dan berbagai faktor yang memengaruhinya. ${ }^{9,10}$

Suku Minahasa adalah suku bangsa yang mendiami wilayah Sulawesi Utara yang terletak pada Indonesia bagian tengah. Daerah Minahasa yang terletak di Provinsi Sulawesi Utara diperkirakan telah dihuni sejak ribuan tahun sebelum masehi. Berdasarkan asumsi peneliti suku bangsa Minahasa berasal dari Formosa Taiwan, Keturunan suku bangsa Austronesia dari Formosa Taiwan yang tengah dalam perjalanan panjang melalui Filipina dan terus ke Sulawesi. Adapun suku minahasa meliputi Suku Tontemboan, Tonsea, Tombulu, Tondano, Pasan, Ponosakan, Toundangow Tombatu, Tou Bantik, dan Tonbabontewu (Manado Tua) Bunaken. ${ }^{11}$

Seorang dokter perlu menguasai pengetahuan tentang mendeskripsikan luka, dengan tujuan untuk mempermudah tugasnya dalam membuat Visum et Repertum (VeR) yang baik dan benar sehingga dapat digunakan sebagai alat bukti yang bisa menyakinkan hakim untuk memutuskan suatu tindak pidana. ${ }^{1}$ Tujuan pemeriksaan kedokteran forensik pada korban hidup ialah untuk membuat VeR dan mengetahui penyebab luka/sakit dan derajat parahnya luka atau sakitnya tersebut. ${ }^{2}$

Berdasarkan uraian di atas maka penulis tertarik untuk mengetahui perubahan warna luka memar pada suku Minahasa, untuk membuktikan apakah faktor kesukuan merupakan salah satu faktor penentu perubahan warna luka memar.

\section{METODE PENELITIAN}

Penelitian ini dilakukan di Kota Manado selama bulan November 2019. Jenis penelitian ialah deskriptif prospektif dengan melakukan pengamatan subyek dari suku Minahasa yang mengalami luka memar. Peneliti mendeskripsikan dan mendokumentasikan warna dari luka memar setiap harinya.

Variabel penelitian yaitu jumlah kasus luka memar, warna luka memar, penyebab luka memar, dan regio luka memar. Pengambilan data dilakukan dengan pengamatan langsung pada subyek penelitian.

\section{HASIL PENELITIAN}

Selama bulan November 2019, didapatkan 5 subyek penelitian berdasarkan kriteria inklusi yaitu pasien dengan luka memar yang onsetnya belum 24 jam dan bersedia untuk diobservasi. Subyek penelitian ialah individu asli suku Minahasa yang bukan hanya tinggal di Minahasa namun merupakan keturunan langsung dari suku Minahasa. Tabel 1 memperlihatkan penyebab luka memar masing-masing subyek.

Tabel 1. Penyebab luka memar

\begin{tabular}{clc}
\hline $\begin{array}{c}\text { No } \\
\text { kasus }\end{array}$ & \multicolumn{1}{c}{$\begin{array}{c}\text { Penyebab } \\
\text { luka memar }\end{array}$} & $\begin{array}{c}\text { Jumlah } \\
\text { kasus }\end{array}$ \\
\hline 1 & Terbentur tangga & 1 \\
2 & Terbentur batu & 1 \\
3 & Terbentur di sepeda & 1 \\
& motor & 1 \\
4 & Terbentur di kursi & 1 \\
\hline
\end{tabular}


Berdasarkan pengamatan yang telah dilakukan pada hari ke 1-2 ditemukan $60 \%$ luka memar dari subyek berwarna merah kebiruan, 20\% berwarna ungu kebiruan, dan $20 \%$ lagi berwarna biru. Pada hari ke 3-4 warna luka memar menjadi $60 \%$ merah kebiruan, 20\% kuning kehijauan, dan 20\% berwarna biru kehijauan. Pada hari ke 5-6 didapatkan $20 \%$ luka memar yang sembuh atau warna kutisnya telah kembali seperti semula dan $80 \%$ berwarna kuning kehijauan. Pada hari ke 7-8 warna luka memar pada $60 \%$ subyek berwarna kuning kehijauan, dan $40 \%$ lainnya telah sembuh. Kemudian pada hari ke 9-10 warna luka memar subyek ialah $20 \%$ berwarna kuning kehijauan dan $80 \%$ telah sembuh. Pada hari yang ke 12 seluruh subyek telah sembuh (Gambar 1).
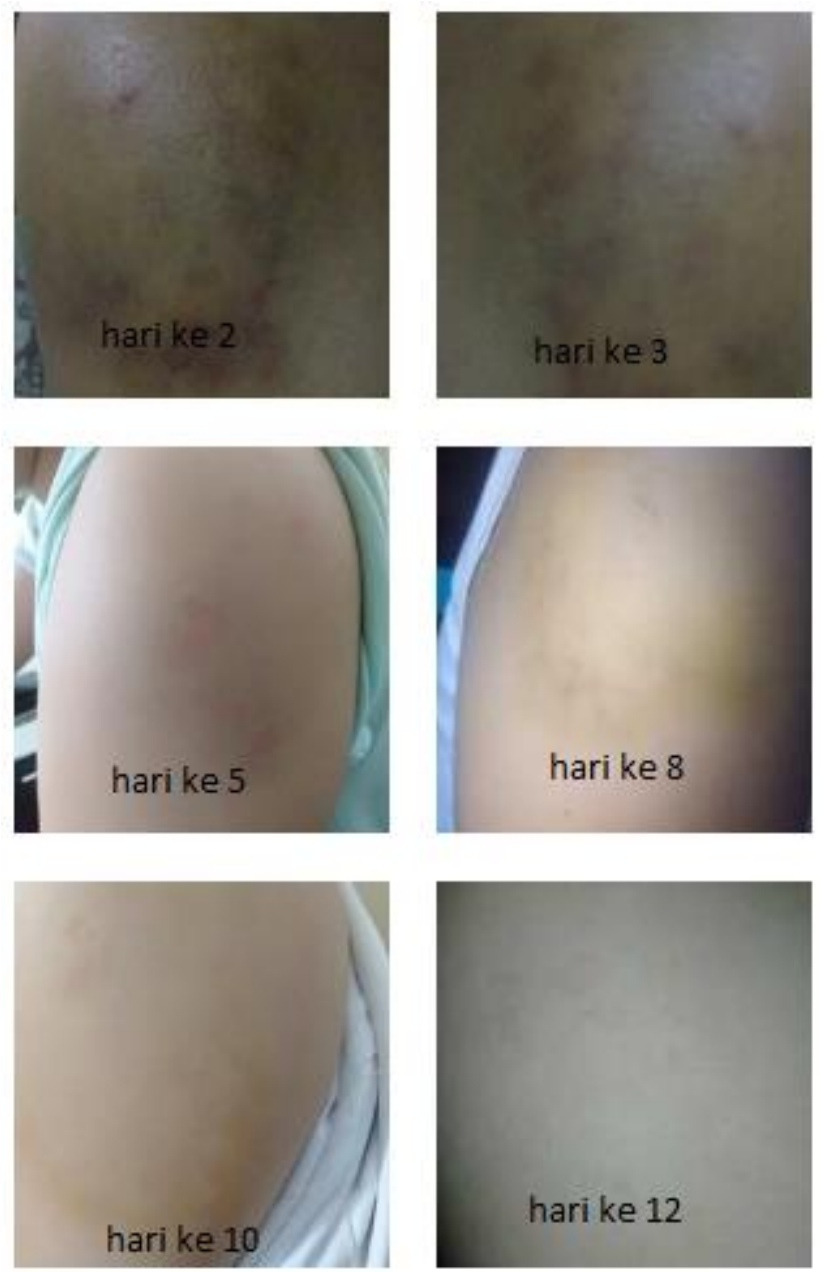

Gambar 1. Perubahan warna luka memar pada salah satu subyek

\section{BAHASAN}

Masyarakat suku Minahasa menurut sejarah merupakan keturunan dari Formosa Taiwan. ${ }^{11}$ Berdasarkan hasil penelitian ini, tidak terdapat ciri khas warna tersendiri pada kulit orang Minahasa. Warna kulit dapat disebabkan oleh berbagai faktor, antara lain oleh adanya pigmen melanin, karoten, dan hemoglobin. Pigmen melanin terutama terdapat pada epidermis yang menyebabkan warna kulit bervariasi dari kuning pucat ke warna gelap dan hitam. Karoten merupakan pigmen kuning-jingga yang terdapat pada stratum korneum dan jaringan lemak kulit dan subkutan. Hemoglobin merupakan pigmen pengangkut oksigen yang terdapat pada eritrosit, yang memberikan warna merah pada kulit. Variasi warna kulit tergantung pada jumlah masing-masing pigmen. ${ }^{12}$

Seorang ahli forensik sering ditanyakan mengenai umur dari memar, dan informasi demikian dapat menjadi sangat penting dalam suatu kasus. Metode yang paling sering digunakan untuk menentukan umur memar ialah perubahan warna dari memar yang terjadi seiring dengan sembuhnya memar. Dalamnya memar dan pigmentasi kulit dapat memberikan efek pada penampakan dan deteksi warna. Umumnya warna memar merah, ungu, atau hitam merupakan perubahan warna yang terjadi secara langsung yaitu dalam waktu periode24 jam setelah cedera. Dalam waktu 24 sampai 72 jam, luka memar dapat menjadi biru, ungu tua, atau coklat. Adanya luka berwarna kuning dapat dilihat pada tahap ini, dan berlangsung selama berhari-hari. ${ }^{8}$

Perubahan warna luka memar pada orang Minahasa relatif sama seperti yang dilaporkan pada penelitian sebelumnya. Pada awalnya berwarna merah kebiruan, berubah menjadi biru atau hitam, kemudian akan berubah lagi menjadi kuning kehijauan sampai warna kuning dan hijau tersebut memudar perlahan-lahan hingga kulit kembali seperti semula.

Proses degradasi haemoglobin pada kulit untuk semua orang sama dan tidak dipengaruhi faktor kesukuan. Luka memar hanya dipengaruhi oleh beberapa faktor 
seperti besar tekanan pada kulit, usia, lokasi, kelainan pembekuan darah, dan penyakit lainnya.

\section{SIMPULAN}

Pada individu suku Minahasa yang mengalami luka memar perubahan warna yang terjadi ialah awalnya memar berwarna merah kebiruan serta menjadi hitam selama kira-kira 1-4 hari, kemudian berubah menjadi kuning kehijauan dan akan memudar secara perlahan-lahan. Faktor kesukuan Minahasa tidak memengaruhi perbedaan pada warna luka memar.

Perlu dilakukan penelitian tentang angka kejadian luka memar, sebab kurangnya data mengenai prevalensi luka memar baik di Sulawesi Utara maupun di Indonesia. Selain itu, perlu digunakan lebih banyak sampel dan jangka waktu penelitian yang lebih panjang agar data yang didapatkan lebih akurat.

\section{Konflik Kepentingan}

Penulis menyatakan tidak terdapat konflik kepentingan dalam studi ini.

\section{DAFTAR PUSTAKA}

1. Idries AM. Pedoman Ilmu Kedokteran Forensik. Jakarta: Binarupa Aksara, 1997.

2. Budiyanto A, Widiatmaka W, Sudiono S, Mun'im TWA, Sidhi, Hartian S, et al. Ilmu Kedokteran Forensik. Jakarta: Bagian Kedokteran Forensik Fakultas Kedokteran Universitas Indonesia; 1997.

3. Ferdinan J, Mistar R. Penilaian Alur Luka untuk Menentukan Penyebab Kematian. Medan: Departemen Ilmu Kedokteran
Forensik dan Medikolegal Fakultas Kedokteran Universitas Sumatera Utara, RSUP H. Adam Malik Medan, 2012.

4. Satyo AC. Aspek medikolegal luka pada Forensik Klinik. Majalah Kedokteran Nusantara. 2006;39(4):430-2.

5. Meikahani R, Kriswanto ES. Pengembangan Buku Saku Pengenalan Pertolongan dan Perawatan Cedera Olahraga untuk Siswa Sekolah Menengah Pertama. Yogjakarta: Jurusan Pendidikan dan Olahraga Fakultas Ilmu Keolahragaan Universitas Negeri Yogyakarta, 2015.

6. Fischer AH. Gender and Emotions. Cambridge: Cambridge Universal Press, 2000.

7. Shkrum MJ, Ramsaytfd DA. Forensic Science and Medicine: Forensic Pathology of Trauma. New Jersey: Human Press Inc, 2007.

8. Damitrias PT, Bhima SKL, Dhanardono T. Hubungan kadar lemak tubuh dengan perubahan warna memar yang dilihat dengan menggunakan teknik fotografi forensik. Jurnal Kedokteran Diponegoro (JKD). 2017;6(2):1073-81.

9. Dodd MJ. Pathological Range of Fire: In the Terminal Ballistics. Boca Raton: CRC, 2006; p. 3577.

10. Enma Z, Kristanto E, Siwu JF. Pola luka pada korban meninggal akibat kekerasan tumpul yang diautopsi di RSUP Prof. Dr. R. D. Kandou Manado periode Januari-Desember 2014. e-Clinic. 2018; 6(1):55-8.

11. Manjo Ka Leilem magazine. Edisi KKN PPM UGM SLU Geothermal: 2015

12. Tortora GJ, Grabowski SR. The integument system. In: Principles of Anatomy and Physiology (9th ed). New York: John Wiley@Sons, 2000; p. 145. 